\title{
Impact of training quality on expected training service prices of learners at Vietnamese public universities
}

\author{
Vu Thi Kim Anh \\ Faculty of Accounting, \\ Trade Union University \\ 169 Tay Son Road, Dong Da District, \\ Hanoi City, 100000, Vietnam \\ Email:kimanhvt@dhcd.edu.vn \\ ORCID ID: https://orcid.org/0000-0003-3647-8041
}

\author{
Hoang Thi Viet Ha \\ Faculty of Accounting and Auditing, \\ Hanoi University of Industry \\ 298 Cau Dien Road, Bac Tu Liem District, \\ Hanoi City, 100000, Vietnam \\ Email: hoangthivietha@gmail.com
}

\begin{abstract}
The research measured and evaluated the influence of 6 factors, namely: program coordination organization, lecturers, training programs, teaching and learning methods, facilities, and personal expectations of students to the expected price of higher education services at Vietnamese public Universities. The results show that all 6 factors had positive effects on the expected price of higher education services. The training program had the strongest impact on the expected price of higher education services, followed by the lecturer factor. On that basis, we propose appropriate recommendations to improve and enhance the quality of higher education services towards sustainable development of higher education for Vietnamese public Universities.

Index Terms-Price of services, Training, University, Expectations, Learners

JEL code-C30,C34,C51,C91
\end{abstract}

\section{INTRODUCTION}

I $\mathrm{N}$ THE current period of comprehensive and deep international integration, higher education quality at institutions must be evaluated by customers. The evaluation results are the basis for institutions to develop improvement plans while continuously improving the training quality. The socialization of education requires education and training to be considered a type of service; however, it is not an ordinary service but a special type of service. It is special because it is related to the product of human knowledge, policy, and society as a whole. With the view that training is a service, the issue here is to manage the cost of that service. Besides, in line with the view that higher education is a type of service, it is also necessary to calculate the operational efficiency of this service. To achieve financial sustainability in teaching and learning, higher education institutions must improve training cost management efficiency based on determining the reasonable price of higher education services. Therefore, besides improving the training quality and building their own "brand", all educational institutions want to solve the issue of determining the price of higher education services so that they have a scientific and practical basis in determining the appropriate tuition fees, which can both offset the training costs and be highly persuasive to be accepted by society and learners.

In the process of the comprehensive reform of higher education in Vietnam, determining the price of higher education services in universities is one of the important issues that require breakthrough management solutions to fully determine the costs of teaching and learning fees and to reasonably share payment responsibilities among the government, the society and learners. Willingness to pay more is measured as the amount or percentage of extra payment for a product with superior performance over those of regular prices. Therefore, the price of higher education services must be determined based on sharing training costs of training institutions with learners or payers through a monitoring mechanism so that they can see if the quality of training activities is worth the cost they have spent or not, thereby deciding whether to continue to choose that institution's services. To contribute to the socialization of finding financial resources for sustainable development of public universities, the price of higher education services needs to be determined appropriately, otherwise, it will affect the quality, content of the training program, the income of the lecturers, etc. (in case the determined price is lower than the training cost). On the other hand, if the price of higher education services offered is higher than the learner's ability to pay, the student may drop out or choose another university, making it difficult to cover the regular expenses and reinvest in the university.

Therefore, the main objectives of this study are: (1) examining the impact of training quality on the expected price of higher education services of learners; (2) evaluating the level of impact of each factor on the expected price of higher education services at Vietnamese public universities.

\section{Literature RevieW}

The birth of training service price (tuition) comes from the concept of cost-sharing [10]; students and parents contribute a part of the cost to the institution to maintain its operations and generate revenue for salary payment, investment in facilities to improve education quality and create favorable learning conditions for learners. The prices of higher education training services can be approached from many different angles. According to [11], they are called tuition fees - a source of revenue for universities that play a role in allocating available resources and giving price signals to consumers (learners). The difference in tuition fees happens when an organization provides products and services with different tuition rates for different learners of the same product - service. The difference is tuition fee requires the provider to understand the efficiency of market segmentation, or the buyer at a low tuition rate will gain profit by offering to another buyer who is charged a higher fee. The study by [13] suggested that the 
difference in university tuition fees is the different rate of tuition fees paid by learners for different universities, majors, types of classes, depending on many influencing factors, to realize the university's goals and mission as well as to fulfill the educational and training functions and roles of that university.

From the point of view of learners and tuition fee payers, higher education services are first and foremost the fees that students have to pay to attend universities. The price of higher education services provides a signal about the average cost or marginal cost of attending college, as well as the financial returns that graduates will receive [11]. The signals provided by higher education service prices help students use resources more rationally [15]. Based on that, students choose programs that are suitable for themselves and their families, as well as their expectations about career and income in the future. If the tuition fee for an educational program is higher than what students can afford and what they expect for future income, they may consider not attending universities, or choosing a different program at a more suitable university. Research by [4] concluded that through paying tuition fees, students are aware of their rights. The higher the tuition fees students pay, the greater the benefits they expect from the university. Thus, it can be seen that the price of higher education services has an impact on both universities and students in improving the quality of teaching and learning, thereby contributing to improving the quality of the entire higher education system.

According to [9], the student-lecturer ratio is negatively related to the tuition rates. Universities in big city centers have higher tuition rates. If the student retention rate in the following year is low compared to the previous year, the tuition rate will increase. When the unemployment rate in the city where the university is located is high, the fees are reduced. The total cost per student is positively related to the tuition rate. The percentage of applicants admitted to universities is inversely related to tuition rates. The group of variables í related to government policy; when universities receive financial subsidies from the government, tuition fees are reduced.

[18] used cross panel data for multivariable regression with 9 independent variables affecting tuition fees: annual expenditures, type of institution, major, the geographic region, academic reputation ranking, the average SAT scores for incoming freshman, the number of full-time faculty, the number of full-time undergraduate students, and university presidents' pay and benefits. Research results show that all 9 factors have a positive effect on tuition rates, in which the strongest correlation is academic reputation ranking and SAT scores.

[14] suggested that the university size, education quality, geography, competition, and the factors of geographical location and competition and subsidies from the government have a positive impact on identifying tuition rates at universities in Japan [14]. Empirical research results show that tuition fees at prestigious universities will be higher than those at lower prestigious universities. In addition, the size of large universities and the possibility of greater government subsidies tend to reduce tuition fees for students. Thus, it can be seen that the reputation of universities in Japan also affects the tuition fees at these educational institutions.

Through the Hedonic model, [15] quantified the relationship between learners' willingness to pay and some quality factors of Vietnamese public universities, including disciplines, groups of training disciplines, forms of training by year and credit, learners' ability to find jobs [15]. According to that study, learners do not want to pay for several quality factors, which higher education institutions are currently very interested in: conditions of facilities, the ratio of faculty members, the percentage of lecturers holding the titles of associate professor and professor; number of internationally published works of education and training institutions...

Through 662 student surveys at 5 public universities, the experimental study by [5] points out that the factor of the ability to accumulate has a negative impact on tuition fee; the factors of lecturers, facilities, program organization and coordination, program content and teaching methods all have a positive impact on expected tuition fees [5]. The study also shows that facilities have the strongest impact on expected tuition while organization and coordination have almost negligible impact on expected tuition fees.

Thus, the above studies show that factors related to the quality of training affect the expected price of higher education services of learners. Students are seen as customers of the university. Students' expectations will be the desire to enjoy high-quality training services. Therefore, universities need to focus on developing and improving endogenous factors affecting the quality of training, which will have the effect of increasing financial resources from the price of higher education services.

\section{Proposed Work}

\section{A. Research Model}

This study inherits the research results of [8], the scale in the HEDPERF model, and the calibrated scales of [13] in line with the actual situation of higher education in Vietnam. The authors use assessment scales for training quality to measure the price expectations of higher education services, thereby giving the proposed research model as shown in Figure 1 .

The model of expected price of higher education services $\mathrm{PRI}=\beta_{0}+\beta_{1} \mathrm{OAC}+\beta_{2} \mathrm{LEC}+\beta_{3} \mathrm{PRO}$

$$
+\beta_{4} \mathrm{TLM}+\beta_{5} \mathrm{FAC}+\beta_{6} \mathrm{EXP}+\varepsilon
$$

In which:

- PRI: Expected price of higher education services

- OAC: Organization and co-ordination

- LEC: Lecturer

- PRO: Training program

- TLM: Teaching and learning methods

- FAC: Facilities

- EXP: Student expectation

- $\quad \beta_{0}, \beta_{1}, \beta_{2}, \beta_{3}, \beta_{4}, \beta_{5}, \beta_{6}$ : Regression coefficient

- $\quad \varepsilon$ : error tolerance 


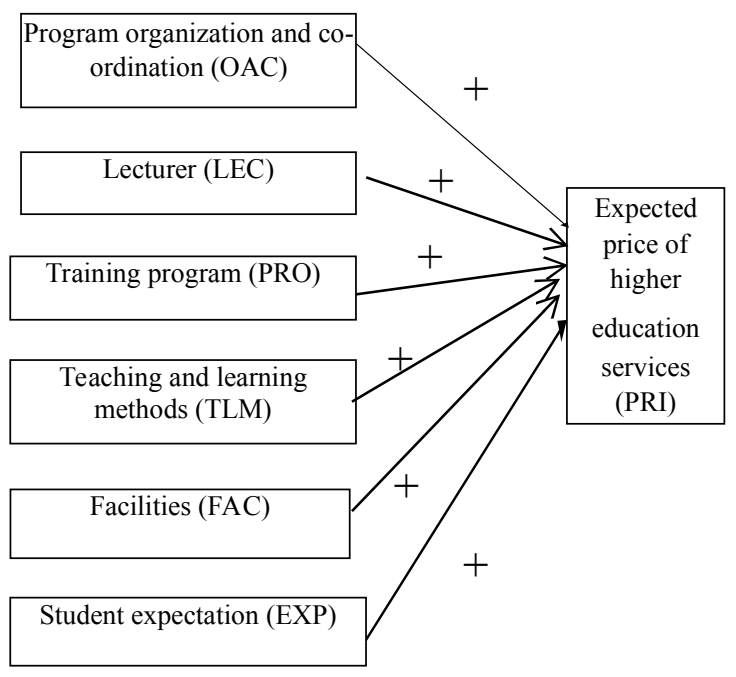

Fig 1. Research model

\section{B. Creating the research scale and hypotheses}

\section{1) Program organization and co-ordination}

According to [11], [6] and [13], when students are satisfied with the service quality and timely support from the university's officers and staff regarding program organization and coordination, they are willing to pay higher prices for higher education services.

Hypothesis H1: There is a positive correlation between program organization and coordination and the expected price of higher education services.

2) Lecturer

[11], [17], [2], [3], [6] and [13] all confirm university faculty is an important factor in determining the improvement and development of training quality in universities. Through professional competencies (professional knowledge, teaching methods, professional ethics of lecturers) and soft skills (actively showing interest in students; encouraging the love of learning, listening skills, skills to adapt well to unexpected situations) applied in teaching, faculty members can ensure positive learning outcomes and stimulate students' interest in learning. Therefore, enhancing the capacity and quality of faculty can lead to an increase in the level of satisfaction and perception of service quality of students [6]. As a result, students are willing to pay for higher prices of higher education services

Hypothesis H2: There is a positive correlation between lecturer and the expected price of higher education services

3) Training program

According to [8] and [13], the content of training programs aims towards standardization - modernization suitable to universities in the region and business requirements, towards the balance between theory and practice of each field and subject in line with requirements of learners and the labor market. Thanks to that, theoretical training is combined with practical applications to build close relationships with businesses, create conditions for students to participate in learning, visiting, and exposure to the real environment. Therefore, when customers are satisfied with the training program they are enjoying, they are willing to pay higher prices for higher education services.
Hypothesis H3: There is a positive correlation between the training program content and the expected price of higher education services

4) Teaching and learning methods

In higher education, the teaching and learning methods play an important role in forming and developing professional competence for students. Studies by [8] and [13] show that learners are very interested in the teaching and learning methods of teachers because it directly affects the knowledge that learners receive in the learning process. Therefore, hypothesis $\mathrm{H} 4$ is stated as follows:

Hypothesis H4: There is a positive correlation between teaching and learning methods and the expected price of higher education services

5) Facilities

[3] and [13] believe that when students are fully provided with relevant support services at universities, this will create the most favorable conditions for learning activities. Although support services do not directly affect the quality of training students receive, when they enjoy better support services, it can increase the level of satisfaction and perception of training service quality of universities. As a result, they will be willing to pay higher tuition fees.

Hypothesis H5: There is a positive correlation between facilities and the expected price of higher education services.

6) Student expectation

The educational product that students receive while studying at universities is a complex product, which includes both tangible product and intangible service aspects. Student expectation is students' belief that after graduation they have jobs that are suitable for their professional qualifications and help improve their self-worth [7], [13]. Therefore, hypothesis H6 is stated as follows:

Hypothesis H6: There is a positive correlation between student expectation and the expected price of higher education services.

7) Expected price of higher education services

The willingness of customers to pay for a service when using it depends on the economic value received and the usefulness of the service [1]. Accordingly, economic value and utility are the two factors that determine the price that a person is willing to accept to pay is the limit price or the maximum price. Thus, the level of willingness to pay (expectation) for higher education services is defined as the highest price that an individual is willing to accept to pay for a service [13].

There is an overview of the observed variables in the research model described in Table 1

\section{TABLE 1}

Description Of The Variables In The Model

\begin{tabular}{|c|l|c|}
\hline $\begin{array}{c}\text { Variable } \\
\text { code }\end{array}$ & \multicolumn{1}{|c|}{ Variable name } & Source \\
\hline \multicolumn{3}{|c|}{ 1. Program organization and co-ordination } \\
\hline OAC 1 & $\begin{array}{l}\text { When students have problems, the } \\
\text { administrative staff does care to help } \\
\text { students solve problems }\end{array}$ & \\
\hline OAC 2 & $\begin{array}{l}\text { The administrative staff always cares and } \\
\text { takes good care of students }\end{array}$ & \\
\hline
\end{tabular}




\begin{tabular}{|c|c|c|}
\hline $\begin{array}{l}\text { Variable } \\
\text { code }\end{array}$ & Variable name & Source \\
\hline OAC 3 & $\begin{array}{l}\text { The administrative staff shows a positive } \\
\text { attitude towards students. }\end{array}$ & \\
\hline \multicolumn{3}{|c|}{ 2. Lecturer } \\
\hline LEC1 & Faculty members are always polite & {$[8],[17]$} \\
\hline LEC 2 & $\begin{array}{l}\text { Faculty members always show a positive } \\
\text { attitude towards students. }\end{array}$ & {$[8],[2]$} \\
\hline LEC 3 & $\begin{array}{l}\text { Faculty members have good teaching } \\
\text { manners. }\end{array}$ & {$[8],[3]$} \\
\hline LEC 4 & $\begin{array}{l}\text { Faculty members always provide } \\
\text { feedback on students' progress during their } \\
\text { studies }\end{array}$ & {$[8],[3]$} \\
\hline LEC 5 & Faculty members are highly qualified & \multirow{3}{*}[8]{$,[6],[13]$} \\
\hline LEC 6 & $\begin{array}{l}\text { Faculty members provide adequate } \\
\text { materials for students }\end{array}$ & \\
\hline LEC 7 & $\begin{array}{l}\text { Faculty members give correct evaluation } \\
\text { and mark }\end{array}$ & \\
\hline \multicolumn{3}{|c|}{ 3. Training program } \\
\hline PRO 1 & Training programs are updated regularly & \multirow{5}{*}[8]{,$[13]$} \\
\hline PRO 2 & $\begin{array}{l}\text { The modules in training programs are } \\
\text { linked together. }\end{array}$ & \\
\hline PRO 3 & $\begin{array}{l}\text { Time is allocated for different subjects in } \\
\text { a way that facilitates student learning }\end{array}$ & \\
\hline PRO 4 & $\begin{array}{l}\text { The objectives of the training programs } \\
\text { are in line with the students' expectations }\end{array}$ & \\
\hline PRO 5 & The duration of the courses is suitable & \\
\hline \multicolumn{3}{|c|}{ 4. Teaching and learning methods } \\
\hline TLM 1 & Teaching methods are appropriate & \multirow[t]{4}{*}[8]{,$[13]$} \\
\hline TLM 2 & Teaching methods are based on practice & \\
\hline TLM 3 & $\begin{array}{l}\text { Teaching methods are modern and apply } \\
\text { information and communication technology }\end{array}$ & \\
\hline TLM 4 & Teaching methods are student-centered & \\
\hline TLM 5 & $\begin{array}{l}\text { Teaching methods promote positivity, } \\
\text { initiative, creativity, and application of } \\
\text { students' knowledge and skills }\end{array}$ & {$[13]$} \\
\hline \multicolumn{3}{|c|}{ 5. Facilities } \\
\hline FAC 1 & $\begin{array}{l}\text { Classrooms make students feel } \\
\text { comfortable }\end{array}$ & \multirow{4}{*}{$\begin{array}{c}{[3]} \\
{[13],[16]}\end{array}$} \\
\hline FAC 2 & $\begin{array}{l}\text { The library has enough seats and group } \\
\text { study rooms }\end{array}$ & \\
\hline FAC 3 & $\begin{array}{l}\text { There are enough teaching and learning } \\
\text { facilities }\end{array}$ & \\
\hline FAC 4 & $\begin{array}{l}\text { There are facilities and grounds for } \\
\text { cultural, artisti,c and sports activities }\end{array}$ & \\
\hline \multicolumn{3}{|c|}{ 6. Student expectation } \\
\hline EXP1 & $\begin{array}{l}\text { Studying at the university helped me gain } \\
\text { the professional knowledge needed to } \\
\text { work }\end{array}$ & {$[8],[3]$} \\
\hline
\end{tabular}

\begin{tabular}{|c|l|c|}
\hline $\begin{array}{c}\text { Variable } \\
\text { code }\end{array}$ & \multicolumn{1}{|c|}{ Variable name } & \multirow{2}{*}{ Source } \\
\hline EXP 2 & $\begin{array}{l}\text { Studying at the university helps me to } \\
\text { have the necessary social knowledge }\end{array}$ & \\
\cline { 1 - 2 } EXP 3 & $\begin{array}{l}\text { Studying at the university helps me } \\
\text { acquire career skills suitable for today's } \\
\text { labor market }\end{array}$ & \\
\cline { 1 - 2 } EXP 4 & $\begin{array}{l}\text { Studying at the university helps me } \\
\text { develop soft skills for work }\end{array}$ & \\
\cline { 1 - 2 } EXP 5 & $\begin{array}{l}\text { Studying at the university helps me } \\
\text { improve my awareness and attitude in life }\end{array}$ & \\
\hline
\end{tabular}

(Source: compiled by the group of authors)

\section{Research Methods}

\section{A. Data collection}

This study uses the quantitative method with a survey questionnaire and a 5-level Liker scale (1-Strongly disagree; 5-Strongly agree) to assess independent factors that affect the expected price of higher education services.

In this study, the sample was selected according to the convenient sampling method, which is disaggregated by university, industry, year, living area to ensure representativeness in assessing the price expectations of higher education services of learners, gender, and gender. For example, students of public universities in Hanoi are summarized in Table 2. The sample size was determined according to [12] based on the minimum sample size $(\min =50)$ and the number of variables in the model. The research model of this paper has 6 variables, so the minimum sample size is 120 . The sample selected for the survey includes 526 students at 5 private universities as follows:

\begin{tabular}{|c|c|c|c|c|c|}
\hline Criteria & $\begin{array}{c}\text { Quantit } \\
\mathbf{y}\end{array}$ & $\begin{array}{c}\text { Percent } \\
\text { age } \\
(\%)\end{array}$ & Criteria & Quantity & $\begin{array}{c}\text { Percentag } \\
\mathrm{e} \\
(\%)\end{array}$ \\
\hline University & & & $\begin{array}{l}\text { No of } \\
\text { Year }\end{array}$ & & \\
\hline $\begin{array}{l}\text { Hanoi University of } \\
\text { Industry }\end{array}$ & 101 & 19.2 & 1 & 67 & 12.74 \\
\hline $\begin{array}{l}\text { Vietnam Trade } \\
\text { Union University }\end{array}$ & 134 & 25,48 & 2 & 211 & 40.11 \\
\hline $\begin{array}{l}\text { Academy of } \\
\text { Finance }\end{array}$ & 82 & 15.59 & 3 & 192 & 36.5 \\
\hline $\begin{array}{l}\text { Thuongmai } \\
\text { University }\end{array}$ & 115 & 21,86 & 4 & 56 & 10.65 \\
\hline \multirow{3}{*}{$\begin{array}{l}\text { University of } \\
\text { Labour and Social } \\
\text { Affairs }\end{array}$} & 94 & 17.87 & Total & 526 & 100 \\
\hline & & & $\begin{array}{c}\text { Living } \\
\text { area }\end{array}$ & & \\
\hline & & & KV1 & 145 & 27.57 \\
\hline \multirow[t]{3}{*}{ Total } & 526 & 100 & KV2 & 227 & 43.16 \\
\hline & & & KV3 & 154 & 29.27 \\
\hline & & & Total & 526 & 100 \\
\hline
\end{tabular}

(Source: the survey done by the group of authors) 


\section{B. Processing survey results}

Data from the survey results are classified and cleaned. After that, analytical tools are used to: (i) calculate the average value of each variable and variables; (ii) verify the reliability of the scale, (iii) perform exploratory factor analysis (EFA); (iv) perform correlation analysis; (v) perform multivariate regression analysis. Based on the results of the analysis, the study conducts a discussion and made recommendations to improve the training quality for universities in line with the roadmap to increase tuition fees when implementing financial autonomy.

\section{Results And Disscussion}

\section{A. Scale evaluation}

Cronbach's Alpha test results of the scales show that all of them are from 0.6 or more (Table 3 ) and the total correlation coefficients of the scales are all higher than the allowed level (greater than 0.3). Therefore, all the scales met the requirements.

Table 3 Cronbach's Alpha Coefficient

\begin{tabular}{|l|l|l|l|}
\hline No & Scale & \multicolumn{1}{|c|}{ Name of factor } & \multicolumn{1}{|c|}{$\begin{array}{c}\text { Cronbach's } \\
\text { Alpha }\end{array}$} \\
\hline 1 & OAC & $\begin{array}{l}\text { Organization and co- } \\
\text { ordination }\end{array}$ & 0,899 \\
\hline 2 & LEC & Lecturer & 0,912 \\
\hline 3 & PRO & Training program & 0,887 \\
\hline 4 & TLM & $\begin{array}{l}\text { Teaching and learning } \\
\text { methods }\end{array}$ & 0,918 \\
\hline 5 & FAC & Facilities & 0,853 \\
\hline 6 & EXP & Student expectation & 0,913 \\
\hline
\end{tabular}

(Source: Data processing results from SPSS 22.0)

\section{B. Exploratory factor analysis (EFA)}

Cronbach's alpha coefficient ensures the reliability of the scales. To analyze the convergence value and discriminant value of the factors affecting the expected price of higher education services at universities, the factors OAC, LEC, PRO, TLM, FAC, EXP are included in EFA analysis; also matrix rotation is used to determine the number of extracted factors to find new factors through Table 4.

\begin{tabular}{|} 
Table 4. Kmo Results and Bartlett Test \\
\begin{tabular}{|c|c|c|l|}
\hline \multicolumn{2}{|c|}{ KMO coefficient (Kaiser-Meyer-Olkin) } & 0,921 & Acceptance \\
\hline \multirow{3}{*}{$\begin{array}{c}\text { Bartlett's test } \\
\text { model }\end{array}$} & Chi-squared value & 5708.671 & \\
\cline { 2 - 5 } & Degree of freedom & 406 & \\
\cline { 2 - 5 } & Sig. (p-value) & .000 & Accepted \\
\hline
\end{tabular}
\end{tabular}

(Source: Data processing results from SPSS 22.0)

The results of Table 4 show that: With $0.5<\mathrm{KMO}=$ $0.921<1$, factor analysis is accepted with the data set of factors. At the same time, with Bartllet test $=0.000<0.05$, factor analysis is appropriate. This shows that the scales of 6 factors (OAC, LEC, PRO, TLM, FAC, EXP) are eligible for EFA analysis. The extracted variance value is $57.09 \%$, which means that $57.09 \%$ of the variation of the factors is explained by the observed variables (Table 5).

\begin{tabular}{|c|c|c|c|c|c|c|c|}
\hline \multirow{2}{*}{$\begin{array}{l}\text { Observed } \\
\text { variables }\end{array}$} & \multicolumn{6}{|c|}{ Factor } & \multirow{2}{*}{ Factor name } \\
\hline & 1 & 2 & 3 & 4 & 5 & 6 & \\
\hline LEC 3 & .855 & & & & & & \multirow{6}{*}{ Lecturer } \\
\hline LEC 5 & .800 & & & & & & \\
\hline LEC 1 & .784 & & & & & & \\
\hline LEC 4 & .732 & & & & & & \\
\hline LEC 2 & .681 & & & & & & \\
\hline LEC 7 & .666 & & & & & & \\
\hline PRO 3 & & .798 & & & & & \multirow{5}{*}{$\begin{array}{l}\text { Training } \\
\text { program }\end{array}$} \\
\hline PRO 2 & & .765 & & & & & \\
\hline PRO 1 & & .709 & & & & & \\
\hline PRO 4 & & .696 & & & & & \\
\hline PRO 5 & & .679 & & & & & \\
\hline TLM 4 & & & .812 & & & & \multirow{5}{*}{$\begin{array}{c}\text { Teaching an } \\
\text { learning } \\
\text { methods }\end{array}$} \\
\hline TLM 5 & & & .799 & & & & \\
\hline TLM 3 & & & .765 & & & & \\
\hline TLM 2 & & & .764 & & & & \\
\hline TLM 1 & & & .601 & & & & \\
\hline FAC 3 & & & & .808 & & & \multirow{4}{*}{ Facilities } \\
\hline FAC 4 & & & & .729 & & & \\
\hline FAC 1 & & & & .727 & & & \\
\hline FAC 2 & & & & .632 & & & \\
\hline OAC 3 & & & & & .873 & & \multirow{3}{*}{$\begin{array}{c}\text { Organizatio } \\
\mathrm{n} \text { and co- } \\
\text { ordination }\end{array}$} \\
\hline OAC 2 & & & & & .855 & & \\
\hline OAC 1 & & & & & .796 & & \\
\hline EXP 1 & & & & & & 0,912 & \multirow{5}{*}{$\begin{array}{c}\text { Student } \\
\text { expectation }\end{array}$} \\
\hline EXP 2 & & & & & & 0,905 & \\
\hline EXP 3 & & & & & & 0,883 & \\
\hline EXP 5 & & & & & & 0,825 & \\
\hline EXP 4 & & & & & & 0,820 & \\
\hline
\end{tabular}

(Source: Data processing results from SPSS 22.0)

In Table 5, the factor loading coefficients all reach values $>0.6$, so 29 observed variables of 6 independent factors are accepted. The factors do not change, only the order of the variables in each factor changes. The exploratory factor analysis results are consistent with the original study design, proving that scales ensure convergent and discriminant validity.

Evaluation of the value of the scale of the dependent variable on the expected price of higher education services.

Because KMO result $=0.725$, satisfying the condition 0.5 $<\mathrm{KMO}<1$, the exploratory factor analysis is suitable for survey data. Barlett's test has Sig. $=0.00<0.05$, so the use of the EFA model to evaluate the value of the scale of expecta- 
tion of the price of higher education services is appropriate. The extracted variance value is 66,697 or $66.69 \%$ of the change of the factor explained by the observed variables. It is concluded that the EFA model is suitable and the scale is accepted.

\section{Multivariate regression analysis}

The results of the regression coefficient test show that the independent variables all have Sig values less than 0.05 . It is concluded that independent variables are significantly and positively correlated with the expected price of higher education services.

Table 6. Analysis Of Factors Affecting The Expected Price Of Higher Education Services

Model Summary

\begin{tabular}{|l|r|r|r|r|r|}
\hline Model & \multicolumn{1}{|c|}{$\mathrm{R}$} & $\begin{array}{c}\mathrm{R} \\
\text { Square }\end{array}$ & $\begin{array}{c}\text { Adjusted R } \\
\text { Square }\end{array}$ & $\begin{array}{c}\text { Std. Error of } \\
\text { the Estimate }\end{array}$ & $\begin{array}{l}\text { Durbin- } \\
\text { Watson }\end{array}$ \\
\hline 1 & $.892^{\mathrm{a}}$ & .795 & .791 & .28091 & 1.284 \\
\hline
\end{tabular}

a. Predictors: (Constant), OAC, LEC, PRO, TLM, FAC, EXP

b. Dependent Variable: PRI

$\operatorname{ANOVA}^{\mathrm{a}}$

\begin{tabular}{|c|c|c|c|c|c|}
\hline Model & $\begin{array}{l}\text { Sum of } \\
\text { Squares }\end{array}$ & $\mathrm{df}$ & $\begin{array}{l}\text { Mean } \\
\text { Square }\end{array}$ & $\mathrm{F}$ & Sig. \\
\hline 1 Regression & 70.292 & 6 & 14.058 & 178.159 & $.000^{\mathrm{b}}$ \\
\hline Residual & 18.070 & 229 & .079 & & \\
\hline Total & 88.362 & 234 & & & \\
\hline
\end{tabular}

a. Dependent Variable: PRI

b. Predictors: (Constant): OAC, LEC, PRO, TLM, FAC, EXP

TABLE 7.

Analysis Of Factors Affecting The Price Of Highereducation Services

\begin{tabular}{|c|c|c|c|c|c|c|c|c|}
\hline & \multirow[b]{2}{*}{ Model } & \multicolumn{2}{|c|}{$\begin{array}{l}\text { Unnormalized } \\
\text { coefficient }\end{array}$} & \multirow{2}{*}{$\begin{array}{c}\begin{array}{c}\text { Norma- } \\
\text { lized } \\
\text { coefficient }\end{array} \\
\text { Beta }\end{array}$} & \multirow[b]{2}{*}{ T-Test } & \multirow{2}{*}{$\begin{array}{l}\text { Sig- } \\
\text { nifi- } \\
\text { cance } \\
\text { level }\end{array}$} & \multicolumn{2}{|c|}{$\begin{array}{l}\text { Multicollinear } \\
\text { Statistics }\end{array}$} \\
\hline & & B & $\begin{array}{l}\text { Stan- } \\
\text { dard } \\
\text { error }\end{array}$ & & & & $\begin{array}{c}\text { Accep- } \\
\text { tance of } \\
\text { the } \\
\text { variable }\end{array}$ & $\begin{array}{c}\text { Vari- } \\
\text { ance } \\
\text { inflation } \\
\text { factor } \\
\text { (VIF) }\end{array}$ \\
\hline \multirow[t]{7}{*}{1} & (Constant) & .124 & .117 & & 1.058 & .291 & & \\
\hline & OAC & .063 & .025 & .101 & 2.529 & .000 & .693 & 1.443 \\
\hline & LEC & .276 & .032 & .333 & 8.531 & .000 & .587 & 1.703 \\
\hline & PRO & .329 & .040 & .360 & 8.207 & .000 & .464 & 2.155 \\
\hline & TLM & .202 & .040 & .224 & 5.042 & .000 & .454 & 2.202 \\
\hline & FAC & .184 & .035 & .195 & 2.338 & .000 & .541 & 1.849 \\
\hline & EXP & .093 & .069 & .125 & 1.192 & .000 & .674 & 1.483 \\
\hline
\end{tabular}

a. Dependent variable: Expected price of higher education services (PRI)

From the results in the regression weight table, the regression equation through the normalized beta coefficient can be determined as follows:

$\mathrm{PRI}=0.360 \mathrm{PRO}+0.333 \mathrm{LEC}+0.224 \mathrm{TLM}$

$+0.195 \mathrm{FAC}+0.125 \mathrm{EXP}+0.101 \mathrm{OAC}$
The model has 6 variables FAC, OAC, LEC, PRO, TLM, EXP all have Sig. $<0.01$, so these variables are significantly correlated with the variable EXP with $99 \%$ confidence.

\section{Multicollinearity test}

Table 7 shows that the VIF coefficients of the independent variables are in the range from 0 to 4 , thereby concluding that the model of factors affecting the expected price of higher education services at universities s does not have multicollinearity phenomenon [19].

The results show that the $F$ test value $=178,159$ with the Sig significance level. $=0.000<0.05$. This proves that the built regression model is suitable for the collected data set. The adjusted R2 value of the regression model is $79.1 \%$, showing that the independent variables included in the model explain $79.1 \%$ of the change of the dependent variable which is the expected price of higher education services, the remaining $20.9 \%$ is the effect of factors other than the model and random error. The analysis results for the VIF coefficients of the independent variables included in the model are all less than 4 , so it can be concluded that there is no multicollinearity phenomenon. Thus, the independent variables are not correlated with each other.

\section{Conclusion and Recommendation}

The results show that all 6 hypotheses H1, H2, H3, H4, H5, H6 are accepted because the factors have a positive effect (positive Beta coefficient) on the expected price of higher education services with the significance level Sig. < 0.05 . However, the importance of each factor according to the degree of influence decreases as follows: training program, faculty, teaching and learning methods, facilities, student expectations, organization and co-ordination contribute $27.1 \%, 25.1 \%, 16.87 \%, 14.68 \%, 9.41 \%$, and $7.6 \%$, respectively, to the impact on increasing the expected price of higher education services. This proves that the better the factors of training quality are and the more they are appreciated, the higher the expected price of higher education services with the increase by $27.1 \%, 25.1 \%$, and $16.87 \%, 14.68 \%$, $9.41 \%$, and $7.6 \%$ from the current price.

Therefore, when public universities improve these factors, this will lead to an increase in financial resources from higher education service prices, specifically:

Firstly, universities should pay attention to improving and renovating the training program content towards standardization - modernization suitable to universities in the region and business requirements, towards the balance between theory and practice of each field and subject in line with requirements of learners and the labor market. Career and start-up centers should be established to train soft skills for students. They should closely link with businesses, thereby promoting theoretical training combined with practical applications and creating conditions for students to participate in learning, visiting, and interacting with the real environment.

Secondly, universities need to improve the quality of faculty by creating conditions for learning opportunities, promoting the selection of faculty to ensure stability in quantity and quality for a long time, increasing research time, adjusting the allowance regime to limit overtime 
work outside the university, and focusing on improving professional qualifications and teaching methods. The reward and promotion regime also needs to change so that salaries and bonuses are calculated based on teaching results, research works, and activities other than teaching.

Thirdly, universities should increase investment in modern facilities to meet the needs of accommodation and practice. It is necessary to ensure ventilation and a reasonable number of seats in classrooms. Professional projector and microphone equipment for teaching are required to adapt to the development of the Industrial Revolution 4.0 and in line with new teaching methods. Such actions will contribute to improving the quality of training - the fourth strongest factor affecting the expected price of higher education services

Fourthly, universities need to improve the role and attitude of the coordination and management department towards students. With the trend of comprehensive innovation in higher education and quality universities moving to a model of full autonomy, operating like businesses, learners need to be cared for in their material and spiritual life... so that they really feel comfortable in all activities at universities.

This article has investigated the influence of factors of higher education service quality on the expected price of higher education services from the point of view of learners. According to research results, when the quality of training is improved to meet the satisfaction of learners, they are willing to pay higher prices for higher education services. Therefore, determining the price of higher education services at universities in general and universities in particular must match the quality of training services, improve competitiveness, ensure training costs and provide accumulation to reinvest in resources of universities. Future studies can use this result and may expand the sample, discover new factors or use the Probit model in combination with a random utility function to consider the impact of factors related to the characteristics of parents and students on the expected price of higher education services, etc., to add scientific value and enrich this research topic.

\section{REFERENCES}

[1] Breidert, C. (2006), Estimation of Willingness-to-Pay: Theory, Measurement, Application, (Springer e-books.) Wiesbaden: Deutscher UniversitSts-Verlag.
[2] Campos, D. F., dos Santos, G. S., and Castro, F. N. (2017), Variations in student perceptions of service quality of higher education institutions in Brazil, Quality Assurance in Education.

[3] Chikazhe, L., Makanyeza, C., and Kakava, N. Z. (2020), 'The effect of perceived service quality, satisfaction and loyalty on perceived job performance: perceptions of university graduates', Journal of Marketing for Higher Education, 1-18.

[4] Callender, C. (2006), Access to higher education in Britain: The impact of tuition fees and financial assistance. In: Teixeira, P.N., Johnstone, D.B., Rosa,M.J. and Vossensteyn, J.J. (eds.) (2006), Costsharing and accessibility in higher education: A fairer deal? Douro Series: Higher Education Dynamics, Vol. 14. Dordrecht, The Netherlands: Springer.

[5] Dung, V.X., Hoa, N., Hang, T.T. (2019), https://tapchitaichinh.vn/ nghien- cuu-trao-doi/yeu-to-tac-dong-den-muc-hoc-phi-ky-vong-taicac-truong-dai-hoc-cong-lap-viet-nam-310312.html.

[6] Farahmandian, S., Minavand, H., \& Afshardost, M. (2013), 'Perceived service quality and student satisfaction in higher education', Journal of Business and Management, 12(4), 65-74

[7] Fatima, S., Ahmed, A., Fatima, S., and Fatima, N. (2018), 'The Role of Student Expectation and Service Quality in Higher Education Institutions of Pakistan', Journal of Management and Research, 5(2), $1-20$.

[8] Firdaus A. (2005), 'HEdPERF versus SERVPERF: The quest for ideal measuring instrument of service quality in higher education sector', Quality Assurance in Education, Vol. 13, no. 4, pp.305 - 328.

[9] Jackson, M.T. (2012), The production of new potato varieties:technological advances, Cambridge University Press, 248261

[10] Johnstone, B. (2003), 'Cost Sharing in Higher Education: Tuition, Financial Assistance, and Accessibility in Comparative Perspective', Czech Sociological Review, 39(3), 351-374.

[11] Jongbloed, B. (2004), Tuition Fees in Europe and Australasia: Theory, Trends and Policies. In Smart, J.C. (ed.), Higher Education, Handbook of Theory and Research, Vol. XIX. Dordrecht: Kluwer, 2004, pp. 241-309.

[12] Hair, J. F., Black, W. C., Babin, B. J. \& Anderson, R. E. (2010), Multivariate Data Analysis: A Global Perspective, New Jersey, Pearson Prentice Hall.

[13] Hung, T.Q. (2016), Policy on university tuition fees in Vietnam', Doctoral thesis, VNU University of Economics and Business

[14] Mizutani, F., Nakayama, N \& Tanaka, T. (2015), Determinants of University Tuition on Japan, Kobe University. OECD [Organization for Economic Co-operation and Development] (2010), Trends Shaping Education-2010, Paris: OECD Publishing.

[15] Nha,P.X. and Hoan, P.X. (2016), 'Scientific basis for determining higher education fees: Results from the HEDONIC model', Journal of Economics and Development, Vol 226, April 2016.

[16] Pedro, E., Mendes, L., và Lourenço, L. (2018). Perceived Service Quality And Student's Satisfaction In Higher Education: The Influence Of Teaching Methods. International Journal for Quality Research, 12(1).

[17] Pheunpha,P. (2019), A Factor Analysis Of Student' Perceived Service Quality In Higher Education. ABAC Journal Vol.39 No.4(OctoberDecember, 2019 pp 90-110).

[18] Tang, T.L., Hsiung, D.S \& Tang, C.S. (2012), 'College tuition and perceptions of private university quality', Inter national Journal of Educational Management, 18(5), 304-316.

[19] Tho, N.D. (2011), Scientific research methods in business: Design and implementation, Labour and Social Publishing House. 